\title{
Strategic Notes on Third Generation Gangs: A Small Wars Journal- El Centro Anthology. By John P. Sullivan, Robert J. Bunker, Editors. Bloomington: Xlibris, 2020. \$26.99.
}

Jonathan D. Rosen

Follow this and additional works at: https://digitalcommons.usf.edu/jss

pp. 129-131

\section{Recommended Citation}

Rosen, Jonathan D.. "Strategic Notes on Third Generation Gangs: A Small Wars Journal-El Centro Anthology. By John P. Sullivan, Robert J. Bunker, Editors. Bloomington: Xlibris, 2020. \$26.99.." Journal of Strategic Security 14 , no. 1 (2021) : 129-131.

DOI: https://doi.org/10.5038/1944-0472.14.1.1930

Available at: https://digitalcommons.usf.edu/jss/vol14/iss1/10

This Book Review is brought to you for free and open access by the Open Access Journals at Digital Commons @ University of South Florida. It has been accepted for inclusion in Journal of Strategic Security by an authorized editor of Digital Commons @ University of South Florida. For more information, please contact digitalcommons@usf.edu. 


\section{Strategic Notes on Third Generation Gangs: A Small Wars}

Journal-El Centro Anthology. By John P. Sullivan, Robert J. Bunker, Editors. Bloomington: Xlibris, 2020. \$26.99. 


\section{Strategic Notes on Third Generation Gangs: A Small Wars Journal-El Centro Anthology. By John P. Sullivan, Robert J. Bunker, Editors. Bloomington: Xlibris, 2020. ISBN: 978-1796095616. Paperback. 674 pages. \$26.99.}

\section{Reviewed by Jonathan D. Rosen}

Strategic Notes on Third Generation Gangs by John P. Sullivan and Robert J. Bunker is a comprehensive anthology that includes essays on a wide range of topics. The strength of this more than 600-page anthology is that it covers many different issues from gangs in Brazil to Colombian criminal bands. Both Sullivan and Bunker have contributed to debates on drug trafficking, gangs, and organized crime in a variety of scholarly and policy outlets. In this work, many essays are written by Bunker and Sullivan, but the book also includes contributions from other well-known scholars. The authors attempt to examine the changing nature of gangs in various complex cases throughout the Americas.

This volume seeks to contribute to the gang and security literature. There is a tremendous breadth of scholarly literature about gangs in the Americas. This anthology provides an in-depth analysis of gangs like Mara Salvatrucha, or MS-13. Mara Salvatrucha began in the 1980 s and was created by Salvadoran youth fleeing the country's violent civil war. Marginalized youth formed the gang, which provided them with a sense of identity and friendship. The United States government began deporting gang members back to El Salvador in the 1980 os and 1990s, which led to an expansion of the gang throughout Honduras, El Salvador, and Guatemala. Today, the gang operates in the Northern Triangle countries, southern Mexico, and more than 40 U.S. states.

It, however, is often difficult to classify gangs and the wide array of criminal groups operating in the Americas. There is more research that needs to be conducted about gangs in the Americas and how these different organizations work with other criminal actors, such as drug cartels. Scholars disagree about how to define gangs like MS-13, which is examined at great length in this work. Classifying gangs, even one's like MS-13 that have been studied in detail, is an arduous-and often 
controversial-task. Some experts, for instance, contend that MS-13 should be considered a street gang as most members are youth that are bounded by a common identity. Yet The Obama administration classified MS-13 as transnational organized crime. This anthology by Sullivan and Bunker provides an interesting perspective about gangs and how to define such criminal organizations. The editors and authors of this volume develop the concept of third generation gangs in a clear and concise manner. I believe these are important conversations and can have an impact not only on the academic community but also the potential policy options. I think that this work can lead to fruitful discussions and can help scholars, who often disagree, with mechanisms for thinking about these very important topics.

Moreover, this anthology covers important issues that have been understudied in the academic literature, such as the role of the prison system. There has been more work in recent years on the relationship between prisons and organized crime. However, this is something that should be studied in-more depth as tough on crime policies have led to overcrowding and have not reduced crime and violence in Latin America. As some scholars note, prisons in countries like Brazil and El Salvador often serve as centers of crime.

Furthermore, compiling an anthology or edited volume is an arduous task given not only the length of the book but also because of the challenge of working with different authors who have different theoretical and methodological orientations. Respectfully, I think that this volume could be strengthened by including more authors. I would have liked to see more from Robert Muggah, Ioan Grillo, and Nathan P. Jones, who appear in the conclusions. It also would be interesting to include people with different perspectives from around the Americas who write on these topics, such as José Miguel Cruz, Luis Enrique Amaya, Sonja Wolf, Desmond Arias, Eduardo Moncada, Angélica Durán-Martínez, Juan Martinez d'Aubuisson, Thiago Rodrigues, and Marcelo Bergman-to name a few individuals.

Overall, I would like to congratulate the editors on compiling a very thorough book. This work challenges the reader to think conceptually about gangs and the power of these criminal organizations. This anthology provides interesting analysis of trends and future challenges. I believe that this volume will be of great interest to not only undergraduate, graduate 
students, and academics but also people working in policy and law enforcement. 